Томаш Врабель

кандидат філологічних наук, дочент кафедри філології, Закарпатський Угорський Інститут ім. Ферениа Ракойі II, orcid.org/0000-0001-5837-5153

Ужггород, Україна, +380503725045 tomashvrabel@gmail.com

\title{
Specifying the assessment of translators' professional competences in the curriculum
}

Анотаиія. У статті розглядається оиінка професійних компетениій студентів спеціальності переклад та ї̈ відображення у робочій програмі. Методику викладання перекладу, на жаль, часто вважають тотожною викладанню іноземної мови. Автор розрізняе переклад як професійну діяльність та лінгвістичний (або педагогічний) переклад. Останній використовується виключно у процесі вивчення іноземних мов для практики й засвоєння мовних конструкцій. У иій роботі зазначаються вимоги до майбутніх перекладачів, які необхідно засвоїти під час вивчення дисципліни. Спеціальна увага приділяється помилкам, викликаним недостатнім володінням перекладацькими компетенціями. $У$ иььому дослідженні описуються навички, які студенти повинні опанувати для того щоб стати професійними перекладачами. Крім того, детально проаналізовано умовні стадї перекладу: перекладаиький аналіз, стадія переформулювання та постперекладаџький аналіз. Автор обтрунтовує думку, що навіть якщо перекладацький аналіз відбувається до перекладу, а постперекладачький аналіз після нього, діяльність між иими стадіями не єлінійною послідовністю. Переклад - творчий прочес і елементи однієї стадії можуть відбуватися на іншій у випадку якщо сегмент тексту необхідо переосмислити або він потребує подальшого аналізу / пояснення. Володіння навичками перекладу можна перевірити усно й письмово у формі поточного й проміжного контролю. Однак, основним видом аудиторного заняття є письмовий переклад, виконаний вдома та його обговорення у групі. Хоча знання тематичної лексики $i \in$ обов'язковим, це не $\epsilon$ підставою підвищувати студентам оцінку за переклад. Проте, недостатньо високі знання лексики або їх відсутність може знизити оиінку. Автор доходить висновку, щзо професійні навички студентів необхідно оцінювати комплексно на підставі перекладу зв'язного тексту. 
Ключові слова: робоча програма, професійні компетениії, педагогічний переклад, перекладацький аналіз, постперекладацький аналіз, поточний контроль, проміжний контроль.

Abstract. The article focuses on assessing the professional competences of students majoring in translation and its reflection in the curriculum. Training in translation is, unfortunately, often treated in the same way as teaching a foreign language. The author distinguishes between translation as a professional activity and linguistic (or pedagogical) translation. The latter is only used in the process of studying foreign languages as a way of practising linguistic patterns and constructions. This paper specifies the requirements that translators-to be have to master during their studies. Special attention is paid to the errors caused by poor mastery of translator's competences. This work describes the skills students have to master to become professional translators. Furthermore, provisional stages of translation are analysed in detail: the pre-translation analysis, the rewording stage, and the post-translation analysis. The author substantiates that even if pretranslation analysis occurs prior to translation, and the post-translation analysis follows it, the activity between these stages is not a linear sequence. Translation is a creative process and elements of one stage can occur at other stages in case a text segment is reinterpreted or needs further analysis / explanation. The mastery of translation can be checked both orally and in written form as a kind of ongoing monitoring and intermediate control. However, the main kind of class activity is written translation done at home and its discussion in the group. It is suggested that knowledge of thematic vocabulary, though obligatory, cannot serve the ground for giving a student a higher mark unlike insufficient or lack of thematic vocabulary knowledge that can lower the mark. The conclusion is drawn that students' professional skills are to be assessed comprehensively based on the translation of a coherent text.

Keywords: curriculum, professional competences, pedagogical translation, pre-translation analysis, post-translation analysis, ongoing monitoring, intermediate control.

Introduction. Lecturers often face the necessity to write new curricula in translation studies reflecting the competence approach. Teaching translation has its own peculiarities that are hidden from a person who is not professionally related to translation either in his qualifications (he ought to have a translator's diploma), or in the sphere of activity (he should teach translation and be a practising translator). More often than not such a person views training in translation in the same way as teaching a foreign language. This is a well-known problem when translation is regarded as a process of substituting source language lexemes with known (studied) target language lexemes. Translation as a professional activity is confused with linguistic (or pedagogical) translation that has a different aim: studying language and practising grammar constructions. We share M. Lederer's view on differentiating 
these types of translation and do not regard pedagogical translation as a professional one [9, p. 133-138].

Modern curricula specify the competences that have to be mastered during the course. To avoid confusion let us clarify the notions of "competence" and "professional competence". The former is understood as "the ability to apply knowledge, skills and experience to succeed in work" [10, p. 10], while the latter presupposes "the ability to act efficiently based on the skills, knowledge and experience in completing a task or a professional assignment [10, p. 10]. Translation is a set of actions and mental processes aimed at achieving a concrete result production of a text that meets the set requirements. As far as translation as a professional activity is a specific complex mental process requiring all-inclusive realization of professional competences, the latter can only be evaluated in a comprehensive way. Means of estimation are uniform for all competences and they are to be mastered in the course of studying any translation discipline. The translator's mastery of professional competences has to be evaluated based on the quality of the ready translation - the level of its adequacy.

A high-quality translation meets a set of requirements. It would be plausible to mention Werner Koller's equivalence criteria (criteria of quality assessment): communication of the source text (ST) information on extralinguistic reality (denotative equivalence); taking into account stylistic peculiarities (connotative equivalence); adhering to the ST's genre characteristics (normative equivalence); adaptation to the level of knowledge of the potential reader (pragmatic equivalence); rendering the same aesthetic effect on the reader as does the ST (formal-aesthetic equivalence) [Lederer 1994, p. 64-65]. V.K. Komissarov's norms of translation include: equivalence, genre, stylistic, target language, pragmatic and conventional [3, p. 227-246]. V.V. Sdobnikov builds the following system of estimating the quality of translation: 1) functional-communicative level; 2) sense; 3) content; 4) formal-1 (peculiarities of the source language (SL); 5) formal-2 (peculiarities of the target language (TL) [7, p. 74-81].

Although there are minor differences between these systems, there are no major controversies between them. They ensure the pragmatic value of the translation (this category determines all the others and is manifested not separately, but through them), comprehensive communication of the author's intention (unless there is another task), comprehensive rendering of the ST's sense, genre and stylistic correspondence to the ST, adhering to the grammatical and lexical norms of the TL. Breach of any of the requirements to translation can be caused by poor mastery or application of various translator's competences. The causes of semantic misrepresentations include translator's improper actions at the level of a) pretranslation; b) interpretation of translation; c) rewording, e.g. non-compliance with the norms, improper application of translation techniques and transformations, etc. Non-compliance with the genre and stylistic norms can testify to poor or lack of mastery of a particular competence, inconsistencies at the level of text interpretation, pre-translation stage, as well as application of translation transformations. 
Misinterpretation of the ST's sense influences its proper understanding by the recipient and is a serious mistake lowering the grade for translation. However, this mistake can be caused by inadequate mastery or application of various professional competences (from misinterpretation of the text and pre-translation stage to the level of rewording).

That is the reason why estimation of translator's professional competences is done in complex via the translation of a coherent text where inconsistencies at one level bring about inconsistencies at other stages or levels.

It should be noted that incorrect identification of lexical units and grammatical phenomena in translation from English into Hungarian, just like their incorrect use in translation from one's mother tongue into a foreign language belong to linguistic competences, not translator's ones. Therefore, even formal failure to comply with the requirement to observe lexical equivalence is a breach of not translator's, but linguistic competence for it is caused not by improper mastery of techniques that are taught during a translation course, but by inadequate development of linguistic competences (i.e. lack of knowledge of vocabulary and grammar). Exceptions include mastery of terminology in a particular subject, as well as knowledge of constructions and means of expressing thoughts.

Methodology. As far as we aim at drawing the readers' attention to significant issues would-be translators ought to take into account from the very start of their training, we will present a list of translator's competences, requirements that professional translators have to master during their study (which takes a lifetime). It is easy to see that these items partially cover each other and it is inevitable, even in authoritative models, for instance, holistic ones. Everything is interconnected and the realization of one set of skills brings about the realization of others. The list is presented not in the order of significance, all the requirements are fundamental and significant.

Results and Discussion. Now, what do we have to acquire, develop, train and improve?

1. Linguistic knowledge and skills, which include vocabulary, grammar, combinability, i.e. the ability to correctly identify and properly use language units, as well as understanding the difference between SL and TL. This item will only function properly in combination with the next one.

2. Text-building (discourse, sociolinguistic, communicative) knowledge and skills that comprise: the ability to build a text in compliance with the communicative task, situation, sphere of communication, genre and stylistic requirements that is applicable to the TL culture and can be properly interpreted there; use (it is interconnected with the previous item), genre (mastery of genre conventions), style (functional style, communicative distance (formality), expressiveness, evaluation, correlation of individual and standard in the text), understanding of appropriateness of means of expression, being aware of the discrepancies between SL and TL.

3. Encyclopaedic / cultural / thematic knowledge that contains knowledge of the world, reality, source and target cultures, understanding the differences between 
the SL and TL cultures (including sociolinguistic ones), specific knowledge in particular spheres the translator specializes in.

The first three items are fundamental, general, and absolutely essential for any translator. Translator's skills will comprise the ability a) to use this foundation correctly and purposefully, b) strengthen and expand it in the required direction (for instance, in the study of a subject, professional use, genre and stylistic characteristics, etc.) Without this foundation there is no translation.

4. The concept of practical experience accumulated by the translators all over the world that embraces the knowledge of standard requirements, solutions, traditions, translation norms, the notion of optimal or typical strategies and solutions for particular texts and situations.

5. The ability to conduct translator's analysis which consists of the ability to analyse the task, situation and text from the translator's point of view, to choose a strategy, to understand what information should be found or specified to ensure proper interpretation (it is related to the pre-translation stage - see next item).

It should be pointed out here that the strategy is usually set out at the time of discussing the task with the client, not after a lengthy "analysis of the text". The translator starts analysing before reading and careful study of the text, when he hears the client say, "I need this contract translated", "I need an interpreter for a conference" or after a quick look at the ST. Later on, the strategy can be corrected if necessary. Translator's analysis does not presuppose analysis of the text only, it covers analysis of the project: from the client's requirements to the analysis of the communicative situation and the ST.

6 . The ability to search for information efficiently that covers the pretranslation stage, i.e. to understand what is to be found, clear up how it is to be done, to be able to do it efficiently and profitably. The former entails ensuring professional quality, the latter involves the correlation of efforts spent and the results gained.

One needs to learn to overcome lack of knowledge or understanding efficiently and set the ground for translation (ways of expression), thus minimizing uncertainty. The translator should have proper knowledge in the subject field to translate adequately, should learn professional use and terminology, overcome other (linguistic) difficulties. One ought to know where and how to search for information efficiently in each particular case, to learn the technique of search, to be able to evaluate information - its adequacy, appropriateness, relevance, credibility and validity.

7. The ability to translate taking into account the communicative aim and situation of the ST. It is the ability to produce a text that functions properly, i.e. a) ensures communication (TT can be interpreted properly), b) can be used purposefully, c) meets the requirements in a particular situation - in full accord with the needs of the client, receiver, particular sociocultural context, current translation norms and traditions (or deviate from them), etc. TT ought to be similar in content to the ST whether it is a full translation, an abstract or review, adaptation of a 
specialized text for the general public, translation of a regular poem in verse or in prose.

It would be plausible to mention the ability to evaluate the TT, i.e. the result whether it is adequate or needs further editing. Here belongs the ability to ensure and take into account the communicative interests of the parties, to avoid and / or eliminate / mitigate the issues of misinterpretation, etc. All these requirements are realized in the TT. However, besides the necessity to know standard and traditional methods, it is necessary to take non-routine decisions.

8. Management and coordination of one's own actions which comprises the ability to reasonably evaluate the difficulty of the translation, to determine the deadline, to assess one's own qualification. This is certainly related to the analysis mentioned above, i.e. knowing what to offer the client, what to explain, what to clear up, and what to agree on. This presupposes the ability to organize one's workflow, to distribute one's efforts evenly and rationally, to evaluate the risks, to build a strategy of conduct, to coordinate one's actions and skills in the course of work to achieve efficiency and profitability.

9. Computer literacy and technical aptitude that presupposes the ability to operate a computer, translation software, other technical equipment used, for instance, by an interpreter.

10. Ability to work in a team. Nowadays, translators interact and cooperate with other subjects, build friendly relations with partners and colleagues. The smallest team includes the translator and the client, however it can be extended by an editor, receiver, consultants, a team of translators, IT specialists, technicians, designers, etc.

11. Knowledge and observance of translator's ethics. One of the most important qualities of a translator is reliability (trust) with respect to the client and one's colleagues. Unfortunately, students hardly realize how important this is. Nobody needs a translator who is not reliable, does not keep his word, does not comply with the agreements, does not submit the translation on time, does not format it properly, does not proofread the TT, or lets his colleagues down, etc. On the other hand, the translator has the right to expect reliability from his partners, including the client.

12. Knowing the organization and ensuring professional activity. It includes issues related to finance and production, getting acquainted with the principles of the profession, workplace equipment, the translation services market, fundamentals of law, e.g. drawing up a contract, copyright protection, freelance work.

13. The ability to explain and substantiate the taken decisions. It is especially important to explain one's decisions at the learning stage. However, explanation might be needed in professional activity as well - while communicating with the client, user, editor, colleagues or critic. Any intuitive decision is to have a rational basis from the translator's point of view that the latter has to be able to set forth.

Another aspect is the knowledge of nomenclature that enables one to speak professionally on translation. It is a means of ensuring professional communication 
with colleagues and partners, as well as an instrument of scientific style of communication used in researches, like course works, diploma theses, etc.

14. The ability to proofread and edit others' texts. This skill can correspond to separate professions (editor, proofreader), however the translator needs it as well. For instance, an editor in a translation agency is to have advanced level translator's skills to be able to evaluate the TT.

15. Lexicographic and terminographic skills that presuppose the ability to search for information, compile vocabularies and terminological bases. These skills are determinant for a separate profession (terminologist, terminographer, lexicographer) that covers the preparation stage of translation.

Let us turn to provisional stages of translation and the kinds of students' activity in the course of their studies. The first one is translation analysis and pretranslation. The students master (or have mastered - depending on the place the course occupies in the curriculum) the technique and methods of translation analysis and pre-translation. They study various kinds (genres) of texts (e.g. commercial correspondence, technical texts, etc.), their stylistic peculiarities, as well as master the skill of comprehensive approach to the text as an object of translation. They also learn the following skills:

- to determine the communicative situation, communicative aim, the receivers and their needs;

- to understand the sense of the text, the author's intention, as well as ways to its clarification;

- to take into account the context;

- to make clear the pragmatic potential of the text and take the decision on the pragmatic aspect of translation;

- to analyse the information in the text, to find out its connection with extralinguistic context;

- to determine the specific character of the ST from the translator's point of view: its genre and stylistic peculiarities, the author's individual style, cultural characteristics;

- to comprehend what information the translator needs to find from external and internet sources for the correct understanding of the text, as well as adequate communication of the ST's sense in the TT;

- to size up translation difficulties of the text both at the lexical and cultural levels;

- to overcome translation difficulties;

- to build an adequate translation strategy based on the conducted analysis.

The students have to be able to make a correct non-verbal pre-translation analysis and, if needed, verbalize it or its elements (for instance, at the posttranslation stage - at the time of discussing the translation and its variants).

The students should have basic skills of using dictionaries and the internet. They have (or obtain, if it is the primary stage of teaching translation) the correct 
understanding of getting ready for translation as a complex process directed at not only search for lexical units and equivalents but also at the translator's receiving all the relevant information necessary to produce high-quality translation. The learners understand that a bilingual dictionary is an insufficient translation tool. They learn about professional use and stylistic peculiarities of texts of different genres.

The students master the following skills:

- to determine what information the translator needs to find from external and internet sources for the correct understanding of the text and adequate communication of the ST's sense in the TT;

- to use various sources of information: specialized literature, internet, databases, etc.;

- to consult with experts;

- to find relevant information: factual, general cultural, specialized one for the adequate understanding of both the ST and the TT;

- to find lexical (and terminological) equivalents;

- to set the search criteria correctly;

- to check the information (proper names, quotations, SL cultural phenomena);

- to compile a glossary for personal use.

Thus, at the pre-translation stage students also acquire knowledge of thematic vocabulary, clichés and usual constructions, i.e. improve their linguistic skills.

At the rewording stage students study written speech, they learn the fundamental difference between translation as a professional activity that they study during classes in practical translation and the linguistic (pedagogical) translation that is simple transcoding and is used during practical English classes to practise and perfect linguistic knowledge and skills. The students develop the skill of comprehensive approach to the text as an object of translation. They learn to regard translation as a holistic process that cannot be viewed as a translation of isolated phrases. The students study the norms of translation, as well as the linguistic and extralinguistic specific character of the kind of translation, they acquire the skills to make an adequate translation based on the conducted analysis. They apply the proper translation techniques at various levels adhering to the norms of translation, thus observing all the above-mentioned requirements to high-quality translation. Furthermore, it would be plausible to specify in the curriculum the ability to properly assess the equivalence of the applied means of translation - the degree of their correspondence to the communicative aim and sense of the ST, as well as editing of the text. At this stage students acquire and improve their knowledge of the thematic vocabulary, terminology, clichés, grammatical constructions, etc.

At the post-translation analysis stage students learn:

- to proofread their own translated text to find misprints, stylistic errors and to correct them during editing; 
- to conduct a well-grounded post-translation analysis of their own and others' translation in the course of discussing student-translator's solutions during classes in practical translation;

- to assess the equivalence of the used translation means;

- to substantiate one's choice, critical comments and suggestions clearly.

In case pre-translation analysis, as the name suggests, occurs prior to translation, and the post-translation analysis follows it, the activity between these stages is not a linear sequence. Some elements of the pre-translation stage can naturally happen during the translation stage. This happens during translation when a text segment is reinterpreted or needs further analysis / explanation. Preparation to translation does not follow strictly the translator's analysis; these processes start at the same time for elements of translator's analysis are elements of preparation. Furthermore, actions described as preparation occur during translation. For instance, in the course of translation the translator realizes that something needs further research and that is natural. Self-editing at the stage of post-translation analysis is closely related to translation.

Therefore, all operations are associated with a particular stage (pre- or posttranslation analysis), however they interact not in a linear sequence, but in a complex and comprehensive way. This proves the complex nature of a) translation, b) teaching translation, and c) assessment of competences.

The level of mastery of various kinds of translation activity is checked both in oral and written forms. In oral form (as a kind of ongoing monitoring) the students submit the translation of a text segment (a paragraph or a phrase), substantiate their translation solutions, analyse and discuss their own and/or other students' translation variants offering constructive criticism, write a (business) letter. The teacher may also check the knowledge of the vocabulary on the theme studied.

In written form (as a kind of ongoing monitoring and intermediate control) the teacher checks written translation tasks. The students translate a text or its segment, write a letter or a lexical dictation on the theme they study and, finally, take test (a written translation of a text).

The final professionally significant skill is the ability to translate adequately within a given time period and it is to be reflected in the curriculum. The results of a test paper in translation enable one to see and assess the level of preparation for practical work in the chosen sphere, i.e. the degree of mastery of the required competences.

It does not seem plausible here to dwell now on the quantitative criteria, i.e. what mistakes correspond to what mark. However, we will draw the reader's attention to the publications trying to classify translator's errors and their assessment in the course of teaching translation $[1$, p. 8-21; 2, p. 514-537; 4, p. 109-125; 5, p. 132-144; 6, p. 199-227; 8, p. 46-48].

The main kind of work during practical classes is written translation done at home and its collective discussion in the group. However, it would be very efficient to give individual tasks to one or several students. When ready, they submit the 
translation to the teacher who checks and marks it. In the course of study, the whole group will undergo this kind of individual monitoring. The problem here is the number of academic hours given for correcting written tests and the latter takes a huge amount of time.

Conclusions. One should remember that knowledge of vocabulary is not a translator's skill, but a linguistic foundation. Thus, teachers must not put a higher mark just because the student knows the relevant lexis. It is a well-known fact that language proficiency does not presuppose the ability to translate. Therefore, instructors in translation should follow a different set of requirements - knowledge of vocabulary is obligatory and cannot improve the student's mark for translation, however, insufficient or lack of thematic vocabulary knowledge can lower the mark. In other words, lecturers should not confuse elements of linguistic and translation training.

Students and their instructors have to be clear about what to strive for in mastering the profession of a translator. Beginners have to realize that mastering the craft does not mean writing a text in a foreign language only. Moreover, they should understand that obtaining the qualification is not a process that finishes right after they receive their diplomas. It is easy to see that it is practically impossible to cover all the items mentioned above during classes in translation in the course of university studies. Numerous skills come with experience and a professional translator's studies last a lifetime.

Furthermore, not all the above-mentioned skills will be checked and assessed during the classes in practical translation, however, those that have to be in compliance with the state standard, will be assessed comprehensively based on the translation of a coherent text.

\section{REFERENCES}

1. Гаврилова Е.В. Теория и практика оценки переводческих ошибок. Прагматико-смысловой подход. Проблемы перевода, языка $u$ литературы. Серия «Язык. Культура. Коммуникация». 2014. Вып. 17. С. 8-21.

2. Гарбовский Н.К. Теория перевода: Учебник. Москва : Изд-во Московского университета, 2007. С. 514-537.

3. Комиссаров В.Н. Теория перевода (лингвистические аспекты): Учеб. для ин-тов и фак. иностр. яз. Москва : Высшая школа, 1990. С. 227-246.

4. Сдобников В.В. Адекватность и эквивалентность как критерии оценки качества перевода. Информачионно-коммуникативные аспекты перевода. 1997. Ч. 1. С. 109-125.

5. Сдобников В.В. Степень естественности перевода как критерий оценки его качества. Перевод и межкультурная коммуникация: материалы науч. конф. «Лингвистические основы межкультурной коммуникации» (Н. Новгород 14-15 ноября 2003 г.) Серия «Язык. Культура. 
Коммуникация». Вып. 4. Н. Новгород : Изд-во НГЛУ им. Н.А. Добролюбова, 2003. С. 132-144.

6. Сдобников В.В., Петрова О.В. Теория перевода: Учеб. для ин-тов и фак. иностр. яз. - Москва : АСТ: Восток-Запад, 2006. С. 199-227.

7. Сдобников В.В. Проблема оценки качества перевода: коммуникативнофункциональный подход. Вестник Нижегородского государственного лингвистического университета. Серия «Лингвистика и межкультурная коммуникация». Вып. 1. Н. Новгород : Изд-во НГЛУ им. Н.А. Добролюбова, 2007. С. 74-81.

8. Шлепнёв Д.Н. К вопросу о типологии ошибок в переводе: целесообразность разграничения переводческих и лингвистических ошибок с точки зрения дидактики и практики перевода. Проблемь теории, практики и дидактики перевода: материалы II международной научной конференции. (Н. Новгород 13-15 апреля 2009 г.) Серия «Лингвистика и межкультурная коммуникация». Вып. 11. Н. Новгород : Изд-во ГОУ НГЛУ им. Н.А. Добролюбова, 2009. С. 46-48.

9. Lederer M. La traduction aujourd 'hui - le modéle interprétatif. - Paris : Hachette, 1994. P. 133-138.

10.http://www.fgosvo.ru/uploadfiles/mo/20111123094149.pdf (accessed on: 25.06.2020). P. 10.

УДК $811.511 .141 ' 28$

DOI: $10.24144 / 2617-3921.2020 .18 .291-300$

Катерина Дудич Лакатош кандидат філологічних наук, дочент кафедри філологї, Закарпатський угорський інститут імені Ференца Ракоиі II orcid.org/0000-0003-1354-4421 Україна, +380999663935 dudicslakatos@gmail.com

\section{Належне ставлення до говірок - запорука ефективного викладання рідної мови}

Анотаиія. $У$ подальшій частині роботи хочемо оприлюднити результати анкетування, проведених протягом останніх 10 років, які торкнулися питання щодо ставлення до угорської мови на різних рівнях закарпатської угорськомовної освіти. Дані дають відомості про те, 